\title{
Explicit Effect of Phyllospheric Microorganism on Growth Promotion of Pearl Millet (Pennisetum glaucum)
}

\author{
Deepika Chaudhary ${ }^{1}$, Rakesh Kumar ${ }^{1}$, Anju Kumari ${ }^{2}, \operatorname{Rashmi}^{1}$ and Raman Jangra $^{1}$ \\ ${ }^{1}$ Department of Microbiology, CCS Haryana Agricultural University, Hisar, India \\ ${ }^{2}$ Center for Food Science and Technology, CCS HAU Hisar, India \\ *Corresponding author
}

\section{A B S T R A C T}

\begin{tabular}{|l|}
\hline Ke y w or d s \\
Pearlmillet, Foliar, \\
Spray, Growth, \\
PGPR.
\end{tabular}

The present investigation aims to explore potential of phyllospheric isolates on pearlmillet. Bacteria from leaves were isolated and tested for their plant growth promoting traits i.e., siderophore production, indole acetic acid, ammonia production and zinc solubilization. Three bacterial isolates were selected and studied in pothouse on pearlmillet by foliar application. Isolate JFS-5 foliar spray exhibited maximum plant height and shoot dry weight. These promising results conclude that bacterial isolates from phyllosphere and their foliar applications can increase plant growth.

\section{Introduction}

Fertilizers are used in large amount by farmers to increase crop production. However, frequent and excessive use of these chemicals has often resulted in adverse environmental effects, disturbing the ecological balance and making plants even more susceptible to pests and diseases (Olajire et al., 2015). Public awareness to these problems has shifted the approach towards some alternative measures. The use of microorganisms is very important as biofertilizers. They are capable to promote plant growth, sustain soil productivity and soil health. The foliar microbial population can have positive, neutral, or negative impact on their hosts (Berlec, 2012; Vorholt, 2012; Bulgarelli et al., 2013; Rastogi et al., 2013). The phyllosphere bacteria have significant effects in the field of agriculture and environment. These may affect the fitness of natural plant populations and quality as well as productivity of agricultural crops. However, there has been little study of bacterial communities on the surface of plants (Kim et al., 2012). The objective of the present investigation was to study the effect of foliar applications of selected isolates on plant growth parameters of pearlmillet in pot house conditions.

\section{Materials and Methods}

\section{Isolation from leaves of pearlmillet}

Leaves sample were collected from CCS HAU farm field during June-July (2014) from 
pearlmillet crop. Isolation of free living diazotrophs was done by using serial dilution method (Lindow et al., 1978) on Jenson's nitrogen free medium. Ten gram of leaf sample was chopped and immersed in $100 \mathrm{ml}$ of sterilized water and shaken for 30 minutes. Leaf washing thus obtained, were serially diluted with sterile distilled water, these plated on $\mathrm{JM}$ plates and incubated at $30^{\circ} \mathrm{C}$ for 6 days. Isolated colonies were purified, maintained on JM slants and stored at $4^{\circ} \mathrm{C}$. Isolates were transferred to fresh JM slants at regular intervals. Composition of Jensen's medium: (g/l, $\mathrm{pH}$ 7); sucrose 20.0, K2HPO41.00, MgSO4. 7H2O.50, $\mathrm{NaCl} .50$, $\mathrm{CaCl} 2.10$, $\mathrm{Na} 2 \mathrm{MoO} 4.2 \mathrm{H} 2 \mathrm{O} .005$, FeSO4.7H2O.050 and Agar-agar 20.0g/l in $1000 \mathrm{ml}$ distilled water (Jensen 1951).

\section{Plant growth promoting attributes}

The functional diversity amongst isolated Azotobacter strains was studied by qualitative screening of their plant growth promoting (PGP) attributes. The production of Siderophore production by the isolates was measured on Chrome Azurol-S (CAS) agar (Schwyn and Neilands, 1987), by measuring the diameter of the zone of the color change from bluish green to orange. Quantitative estimation of the indole acetic acid (IAA) was carried out by inoculating $1 \mathrm{ml}$ of the respective bacterial suspension $\left(07 \mathrm{CFU} \mathrm{ml} \mathrm{m}^{-1}\right.$ ) in $10 \mathrm{ml}$ Luria Bertani (LB) broth containing L-tryptophan $\left(100 \mu \mathrm{g} \mathrm{ml}^{-1}\right)$, and incubating it in the dark for $48 \mathrm{~h}$. The concentration of IAA in the culture supernatant was estimated by the procedure of Gordon and Weber (1951). All the isolates were tested for their ability to excrete ammonia by growing the cultures in $30 \mathrm{ml} \mathrm{JM}$ broth. The flasks were incubated at $30^{\circ} \mathrm{C}$ for 12 days under stationary conditions. Aliquots of the culture broth were withdrawn and centrifuged at 10,000 rpm for $15 \mathrm{~min}$. Ammonia released in the supernatant was determined according to the method of
Chaney and Marbach (1962). Solubilisation of zinc were assessed according to the procedure of Saravanan et al., (2007) using nutrient agar medium containing $0.1 \%$ insoluble zinc compounds $[\mathrm{ZnO}, \mathrm{ZnS}$, $\mathrm{Zn}_{3}\left(\mathrm{PO}_{4}\right)^{2}$ and $\left.\mathrm{ZnCO}_{3}\right]$, respectively. Three Azotobacter strains were selected for pot house study on the basis of their growth promoting attributes.

\section{Foliar application of selected Azotobacter strains on leaves of Pearlmillet}

The effect of selected Azotobacter strains on the growth of Pearlmillet (Pennisetum glaucum) var. HHB-67 was studied under pot house conditions. Experiment was done with three treatments using two doses of fertilizer $75 \%$ and RDF with control (without culture), respectively. Selected three isolates were grown in Jensen's nitrogen free broth. These cultures were centrifuged and cell pellets was washed twice.

These washed cells were further used for foliar applications in Pearl millet done after 30 days of germination. Plant height and shoot dry weight were determined at 60 days of sowing. Total bacterial and Diazotrophs count were also determined after 30 days (before foliar application) and 60 days of sowing.

\section{Results and Discussion}

Phyllosphere bacterial communities have potential to influence plant biogeography and ecosystem function through their influence on the fitness and function of their hosts. In this study, total 14 bacterial isolates were obtained from phyllosphere of pearlmillet crop on Jensons nitrogen free medium Petriplates. These all strains were studied for different plant growth promoting attributes i.e., IAA, Ammonia, Siderophore production and Zinc solubalization. 


\section{Plant growth promoting attributes}

All 14 Azotobacter strains produced ammonia and IAA while only 8 strains produced siderophore. Out of 14 isolates, 7 strains exhibited solubilisation of Zinc respectively (Table 1). Among PGP activities, IAA and Ammonia producing strains were highest (100 $\%)$ when compared to Siderophore production (57.14 \%), zinc solubilisation (50\%). Strain JFS-5 showed highest IAA production (13.50 $\left.\mu \mathrm{g} \mathrm{m}^{-1}\right)$ and Ammonia excretion $\left(4.70 \mu \mathrm{g} \mathrm{ml}^{-}\right.$ ${ }^{1}$ ). Highest solubilisation of Zinc was shown by strain JFS-10 (39 mm). Siderophore production maximum by JFC-1 (18 $\mathrm{mm})$ exhibited (Table 1). Enya and co-worker (2007) studied that phyllospheric Sphingomonas spp. also produce IAA. Along with phytohormone production, plant growth promotion is known to be mediated by a variety of mechanisms including solubilisation of phosphorus, potassium and zinc, production of ammonia, siderophores and HCN (Dursun et al., 2010; Eman et al., 2011; Mwajita et al., 2013). Ferrara et al., (2012) observed that the endophytic diazotrophs from sugarcane roots are able to produce plant growth-promoting substances and to secrete higher amounts of amino acids that might facilitate plant nutrition.

\section{Effect on pearl millet growth after spray bioinoculants on leaves}

Azotobacter strains isolated from leaves of pearl millet were used for studies on Pearl millet crop under pot house conditions. There was significant increase in Plant height and shoot dry weight of Pearl millet. Maximum increase in plant parameters was observed with Azotobacter strain JFS-5 at fertilization dose of N P K. Maximum plant height (51 $\mathrm{cm})$ and shoot dry weight $(910 \mathrm{mg})$ was observed with foliar spray of JFS-5 with recommended dose of fertilizers followed by JFC-1 plant height $(48.66 \mathrm{~cm})$ shoot dry weight $(890 \mathrm{mg}$ ) and JFS-10 over the control. This reflects the positive effect of foliar application of isolates (Fig. 1 and Fig. 2). Studies on survival count of total bacterial and diazotrophs population increased at 60 days of leaves sampling as compared to initial observation before spray of bacteria on leaves (Fig. 3). Isolate JFS-5 with RDF showed maximum bacterial counts $\left(\mathrm{cfu} \mathrm{m}{ }^{-1}\right.$ ) at 60 days as compared to other isolates and control.

Table.1 Production of different beneficial properties by phyllospheric isolates

\begin{tabular}{|c|c|c|c|c|c|}
\hline $\begin{array}{c}\text { Serial } \\
\text { No. }\end{array}$ & Isolates & $\begin{array}{c}\text { IAA }(\mu \mathrm{g} \\
\left.\mathrm{ml}^{-1}\right)\end{array}$ & $\begin{array}{c}\text { Ammonia } \\
\left(\mu \mathrm{g} \mathrm{ml}^{-1}\right)\end{array}$ & $\begin{array}{c}\text { Zinc solubilization } \\
\text { Zone Diameter } \\
(\mathrm{mm})\end{array}$ & $\begin{array}{c}\text { Siderophore } \\
\text { production } \\
(\mathrm{mm})\end{array}$ \\
\hline 1. & JFC1 & 8.05 & 0.10 & $\mathbf{3 2}$ & 18 \\
\hline 2. & JFL2 & 9.64 & 0.03 & - & - \\
\hline 3. & JFL3 & 8.47 & 0.10 & - & - \\
\hline 4. & JFS4 & 9.22 & 0.49 & - & 13 \\
\hline 5. & JFS5 & $\mathbf{1 3 . 5 0}$ & $\mathbf{4 . 7 0}$ & 21 & 11 \\
\hline 6. & JFS6 & 10.76 & 0.80 & 26 & - \\
\hline 7. & JFS7 & 11.21 & 1.37 & 27 & 10 \\
\hline 8. & JFS8 & 11.72 & 2.36 & - & 11 \\
\hline 9. & JFS9 & $\mathbf{1 2 . 8 1}$ & 4.02 & - & 14 \\
\hline 10. & JFS10 & 9.98 & 4.01 & $\mathbf{3 9}$ & - \\
\hline 11. & JFS11 & 7.59 & 4.52 & 31 & - \\
\hline 12. & JFS12 & 11.30 & 4.51 & - & 14 \\
\hline 13. & JFS13 & 11.66 & 4.59 & 10 & - \\
\hline 14. & JFS14 & 10.46 & $\mathbf{4 . 6 9}$ & - & \\
\hline
\end{tabular}


Fig.1 Effect of phyllospheric selected isolates on plant height of pearlmillet after 60 days plant growth

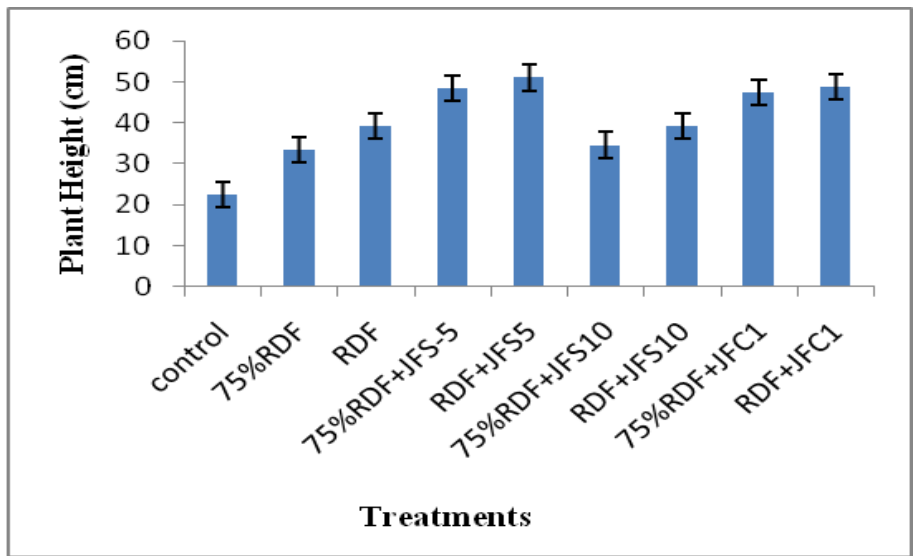

Fig.2 Effect of phyllospheric selected isolates on shoot dry weight of pearlmillet after 60 days plant growth

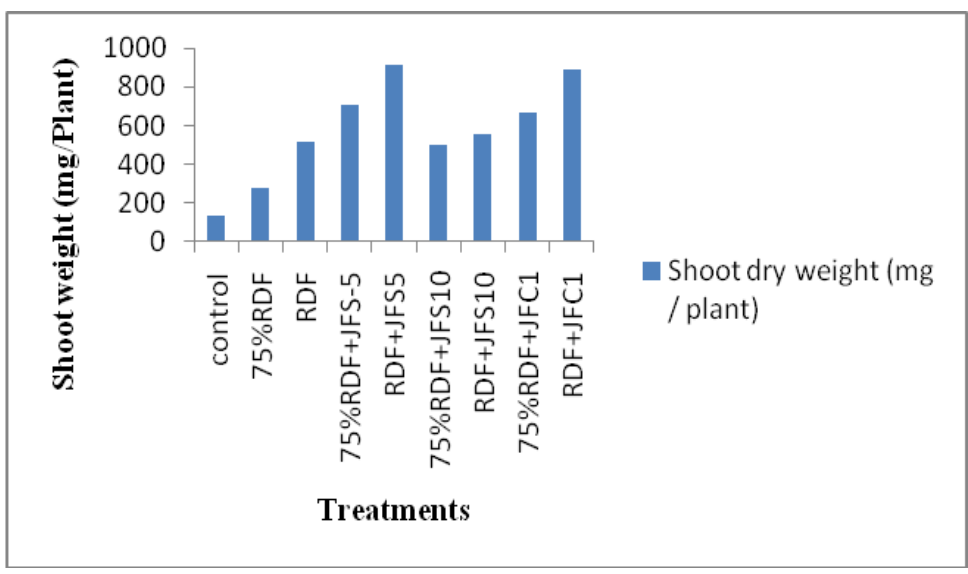

Fig.3 Survival count of bacteria on leaves of pearlmillet at 30 and 60 days

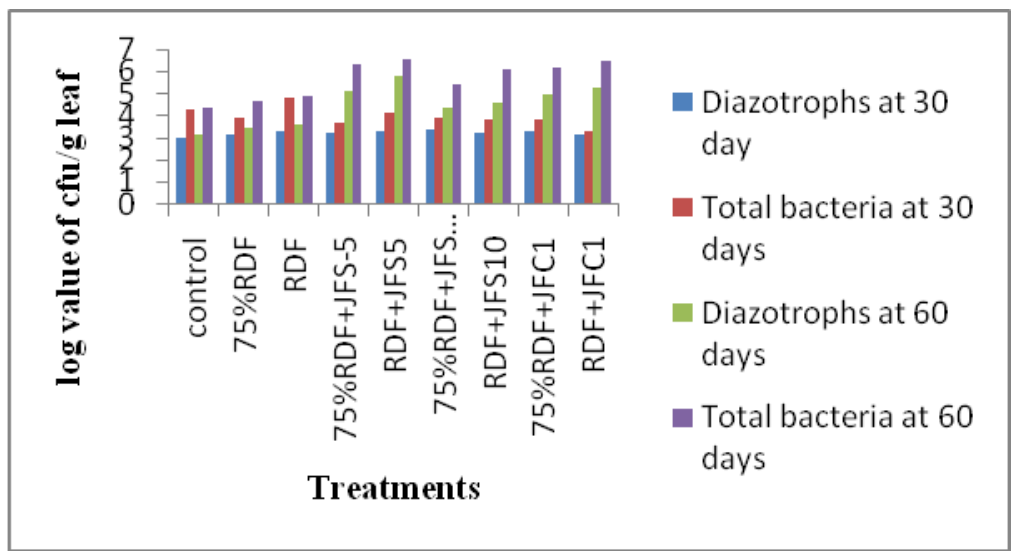


Diazotrophs count was maximum showed also by JFS-5 + RDF i.e., $5.78 \log$ value of $\mathrm{cfu}^{-1}$. There was significant increase in the population of bacteria on leaves those applied bioinoculants in spray as compared to control treatment.

Esitken et al., (2010) studied the effect of bacteria as root inoculation and foliar spray on leaves of strawberry cv. Fern. They found that both root inoculation of Bacillus M3 and spraying of Pseudomonas BA-8 or Bacillus OSU-142 have potential to increase the yield, growth and $\mathrm{P}, \mathrm{Fe}, \mathrm{Cu}$ and $\mathrm{Zn}$ content of the strawberry plant and to increase the soil $\mathrm{P}, \mathrm{Fe}$, $\mathrm{Zn}, \mathrm{K}$, and $\mathrm{Mg}$ availability. Root inoculation of M3 and floral and foliar spraying of OSU142 and BA-8 bacteria stimulated plant growth resulting in significant yield increases. Saa et al., (2015) studied the effect of one biostimulant derived from sea weed extraction (Bio-1) and another biostimulant derived from microbial fermentation (Bio-2) on 2-years-old almond plants over two growing seasons in different treatment i.e., two soil potassium treatments (12511 $\mu \mathrm{gg}$-of Kvs. $5 \mu \mathrm{gg}-)$ and four foliar treatments (No spray,Foliar-K,Bio1,Bio-2). Rubidium was utilized as a surrogate for short-term potassium uptake and plant growth, nutrient concentration, and final plant biomass were evaluated. There was a substantial positive effect of both biostimulant treatments on total shoot leaf area, and significant increases in shoot length and biomass under adequate soil potassium. In conclusion all foliar application of selected Azotobacter isolates treatments has positive effect on growth of pearlmillet crop. These can be a promising alternative as foliar biofertilizer for sustainable and organic agriculture system to mitigate problems associated with use of chemicals fertilizers.

\section{References}

Berlec, A. 2012. Novel techniques and findings in the study of plant microbiota: search for plant probiotics. Plant Sci., 193: 96-102.

Bulgarelli, D., Schlaeppi, K., Spaepen, S., Themaat, E. and Lefert, P. 2013 Structure and functions of the bacterial microbiota of plants. Annual Review of Plant Biol., 64: 807-838.

Chaney, A.L. and Marbach, E.P. 1962 Methods for evaluating biological nitrogen fixation. In F. J. Bergersen (ed.) Clinical chemistry 8: 130. John Wiley and Sons, New York, USA.

Dursun, A., Ekinch, M. and Donmez, M.F. 2010. Effects of foliar application of plant growth promoting bacterium on chemical contents, yield and growth of tomato (Lycopersicon esculentum L.) and cucumber (Cucumis sativus L.). Pak. J. Bot., 42: 3349-3356.

Eman, A., Wafaa, E.K. and Elsisi, A.A.Z. 2011. Effect of foliar application of some growth promoters on growth, fruiting and fruit quality of sultani fig trees. J. Agri. Environ. Sci., 10: 1-10.

Enya, J., Shinohara, H., Yoshida, S., Negishi, T.T.H., Suyama, K. and Tsushima, S. 2007. Culturable leaf-associated bacteria on tomato plants and their potential as biological control agents. Microbial Ecol., 53: 524-536.

Esitken, A., Yildiz, H.E., Ercisli, S., Donmez, M., Turan, M. and Gunes, A. 2010. Effects of plant growth promoting bacteria (PGPB) on yield, growth and nutrientcontents of organically grown strawberry. Scientia Horticulturae, 124: 62-66.

Ferrara, F.I.S., Oliveira, Z.M., Gonzales, H.H.S., Floh, E.I.S. and Barbosa, H.R. 2012. Endophytic and rhizospheric enterobacteria isolated from sugar cane have different potentials for producing plant growth-promoting substances. Plant and Soil, 353: 409- 417. 
Gordon, S.A. and Weber, R.P. 1951 Colorimetric estimation of indoleacetic acid. Plant Physiol., 26: 192-195.

Jensen, V. 1951 Notes on biology of Azotobacter. Proceeding Society for Appl. Bacteriol., 74: 89-93.

Kim, M., Singh, D., LieHoe, A., Go, R., Rahim, A.R., Ainnuddin, A.N., Chun, J. and Adams, M.J. 2012. Distinctive phyllosphere bacterial communities in tropical trees. Microbial Ecol., 63: 674681.

Lindow, S.E., Arny, D.C. and Upper, C.D. 1978. Distribution of ice nucleationactive bacteria on plants in nature. Appl. Environ. Microbiol., 36: 831-838.

Mwajita, M.R., Murage, H., Tani, A. and Kahangi, E.M. 2013, Evaluation of rhizosphere, rhizoplane and phyllosphere bacteria and fungi isolated from rice in Kenya for plant growth promoters. Springer Plus, 2: 606.

Olajire, A.B.L., Dada, O.V., Waha, O.M. and Ojo, O.L. 2015. Effects of fertilizers on soils microbial growth and populations: a review. American J. Engi. Res., 4: 5261.
Rastogi, G., Coaker, G.L. and Leveau, J.H. 2013. New insights into the structure and function of phyllosphere microbiota through high-throughput molecular approaches. FEMS Microbiol. Lett., 348: 1-10.

Saa, S., DelRio, A., Castro, S. and Brown, P. 2015. Foliar application of microbial and plant based biostimulants increases growth and potassium uptake in almond. Frontiers in Plant Sci., 6: 1-9.

Saravanan, V.S., Madhaiyan, M. and Thangaraju, M. 2007. Solubalization of zinc compounds by the diazotrophic, plant growth promoting bacterium Gluconacetobacter diazotrophics. Chemosphere, 66: 1794-1802.

Schwyn, B. and Neilands, J.B. 1987. Universal chemical assay for the detection and determination of siderophores. Anal. Biochem., 160: 4756.

Vorholt, J.A. 2012. Microbial life in the phyllosphere. Nature Rev. Microbiol., 10: 828-840.

\section{How to cite this article:}

Deepika Chaudhary, Rakesh Kumar, Anju Kumari, Rashmi and Raman Jangra. 2017. Explicit Effect of Phyllospheric Microorganism on Growth Promotion of Pearl Millet (Pennisetum glaucum). Int.J.Curr.Microbiol.App.Sci. 6(3): 1046-1051. doi: https://doi.org/10.20546/ijcmas.2017.603.121 